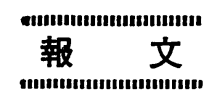

\title{
金属被覆シリンダライナの耐キャビテーション腐食*
}

\author{
露 木 昭 治** 多羅尾光一郎** 藤 井 穆** 由 利三 郎**
}

\section{Cavitation Corrosion Resistance of Metallic Coatings on Water Side of Diesel Cylinder Liner}

\author{
Shôji Tsuyuki, Kôichirô Tarao, Akira Fujii and Saburô Yuri
}

The original cavitation erosion resistance of various metallic coatings has been investigated with the measurement of the natural electrode potential of test pieces under cavitation condition on the magneto-striction vibrator.

The cavitation fatigue diagrams (S-N diagrams) which relate to stress amplitude and repeated number have been investigated about various metallic coatings on cast iron.

The order of resistance to cavitation is as follows:

Electroplating of triple layers with bronze $(25 \mu)$, $\mathrm{Ni}(25 \mu)$ and $\mathrm{Cr}(7 \mu)>$ SUS 27 metalicon $>$ elec tro plating with bronze $(20 \mu)>\mathrm{Al}$ hot dipping $>\mathrm{Zn}$

\section{1. 緒言}

ディーゼル機関シリンダライナの水側には孔食, キャ ビテーション腐食, スキマ腐食, 腐食疲れなど種々の現 象が現われ不測の損傷により寿命を早めることがあるの で，ポーラスクロムメッキなどによる内面腐食摩耗防止 の向上とともに徉来の 3 倍もの延長走行キロに耐える防 食対策が要望されるようになってきた。

シリンダライナの損傷はライナ壁の振動による断続的 キャビテーションの発生に起因する，いわゆるキャビテ ーション・コロージョン領域で発生するものが多い。従 って防食対策として泠却水用腐食抑制剤が広く適用され ており，栄，鬼村1）ら注舶用機関でその適用方法を確立 し, 車輛用機関でも効果が認められたが, 機関形式によ っては十分でなく，さらに金属被覆の必要を認めた2)。

磁わい（歪）振動法により，クロムメッキ鋼のキャビ テーション損傷を一定試験時間後の試験片の重量減から 求め, これより耐久有効膜厚などを検討したり ${ }^{3)}$, 回転 円盤法により被覆相互のキャビテーション損傷を侵食容 量で比較しているものもあるが4), これらの方法による と試験条件を一定にしても被覆の種類, 膜厚その他物理 的性質が異なるとき, 耐エロージョン性を評価し難い場

* 昭和 38 年 10 月 17 日 第 10 回腐食防食討論会 (宝塚)に招いて発表

** 鉄道技術研究所 (東京都北多摩郡国分寺町) metalicon.

A few coatings were applied to prevent cavitation pittings to MAN type engine cylinder liner in inhibited coolants.

The results of these tests showed the electroplating of triple layers with bronze, $\mathrm{Ni}$ and $\mathrm{Cr}$ proved to be free from cavitation-corrosion damage, and stainless steel metalicon, Al hot dipping and $\mathrm{Zn}$ metalicon were partially damaged after about $200,000 \mathrm{~km}$ running. The maximum depth of pitting was estimated to be $1.5 \sim 3.0 \mathrm{~mm} / 200,000 \mathrm{~km}$ running, and no crack was observed in these damaged parts.

合がある。

したがって，筆者らは磁わい振動法に掞いて，キャビ テーション発生下の自然電極電位の挙動から被覆の破壊 までに要する時間を推定し被覆相互の耐キャビテーショ ン性を評価する方法を各種金属被覆鋳鉄について試み た。あわせて代表的金属被覆ライナの現車試験より耐キ ヤビテーション損傷性について対比するとともに防食対 策を検討した。

\section{2. キャビテーション損傷試験方法}

実験装置は図 1 に示す磁わい振動式キャビテーション

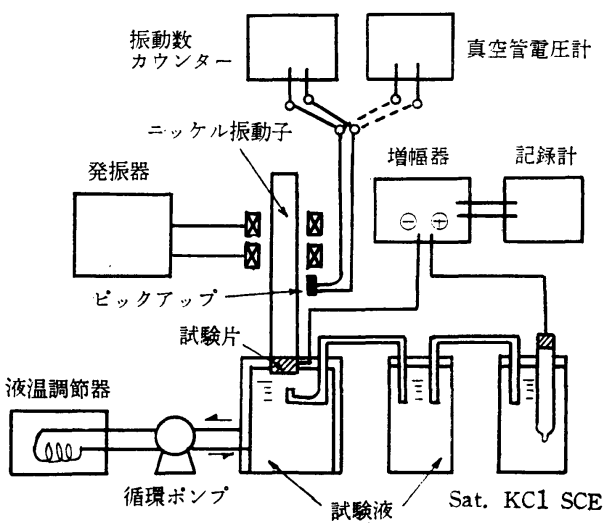

図 1 試験装置略図 
損傷試験装置で，概要は次のとおりである。

振動子: ニッケル磁わい式, 発振器出力: $500 \mathrm{~W}$, 共 振周波数: $6.7 \mathrm{kc}$, 振幅: 最大 $8 / 100 \mathrm{~mm}$

振幅の制御は，あらかじめ振動子側面に貼布したピッ クアップの発生電圧と振動子端の顕微鏡測定振幅とより 求めた図 2 の関係図を作製しておき，発生電圧を監視し ながら発振器の出力電流を加減して行なう。周波数は発 生電圧を電子管式直読カウンターに入れてチェックす る。実験は試験片の重量減少の測定，顕微鏡観察または フェロキシル試験による素地露出点の観測を行ない, 別 に飽和甘承電極に対する自然電極電位の変動を振動容量 形電位差計（内部抵抗 1011 $\Omega$ ） を介して記録する。

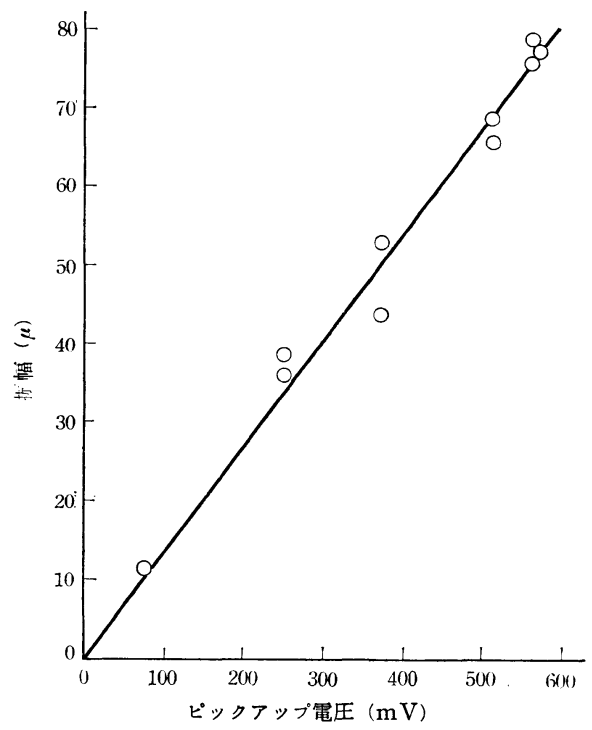

図 2 ピックアップ電圧と振幅関倸図

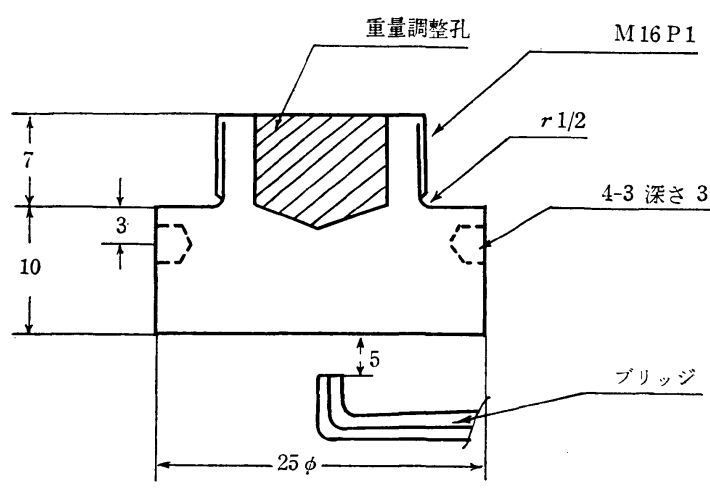

図 3 腐食試験片

腐食液に脱塩水 $\left(18^{\circ} \mathrm{C}\right.$ において $\left.10^{6} \Omega-\mathrm{cm}\right)$ または $1,000 \mathrm{ppm}$ 食塩水を用い, 液温は $25 \pm 1^{\circ} \mathrm{C}$ とした。

試験片の林質は FC 20, 成分（\%) は全炭素：3.43, $\mathrm{Si}: 1.27, \mathrm{Mn}: 0.52, \mathrm{P}: 0.126, \mathrm{~S}: 0.106$, その形状寸
法は図 3 に示したとおりで，これに次の供試被覆を施 す。

（1）青銅メッキ：シアン銅 17 , 錫酸ナトリウム 80 , シアンナトリウム 25 , 水酸化ナトリウム 15 各 $\mathrm{g} / l$ の 組成を有するアルカリ性浴, $D=5 \sim 7 \mathrm{~A} / \mathrm{dm}^{2}, T=50 \sim$ $60^{\circ} \mathrm{C}$, 陰極回転, 極性転換（正 30 秒, 負 5 秒, 電流比 $3: 1)$, Sn $10 \sim 12 \%$

(2) ニッケルメッキ: ワット采光沢液, 硫酸ニッケル 240 , 塩化ニッケル 45 , ホウ酸 30 , ホルマリン $1.5 \sim 2$, 1.5 ナフタリンスルホン酸ナトリウム 7 各 $\mathrm{g} / l$ の組成, $D=3 \sim 5 \mathrm{~A} / \mathrm{dm}^{2}, T=40 \sim 50^{\circ} \mathrm{C}$

(3) クロムメッキ: クロム酸 250 , 硫酸 2.5 各 $\mathrm{g} / l$ の標準液, $D=40 \sim 50 \mathrm{~A} / \mathrm{dm}^{2}, T=45 \sim 55^{\circ} \mathrm{C}$

（4）ステンレス鋼溶射; 下地被覆：Mo> $>99 \%$, 主溶 射: SUS 27, 平均膜厚 $300 \mu$

(5) 亜鉛溶射; 平均膜厚： $120 \mu$

(6) 溶融アルミニウムメッキ; $\mathrm{Al}: 99.8 \%, 760^{\circ} \mathrm{C}$, 7 分間処理

\section{3. 試験結果および考察}

\section{$3 \cdot 1$ メッキ膜厚と耐エロージョン性}

クロムメッキのキャビテーション・ピッティング数と 試験時間の関係を図 4 に示す。曲線の立上り時間 $(N \fallingdotseq$

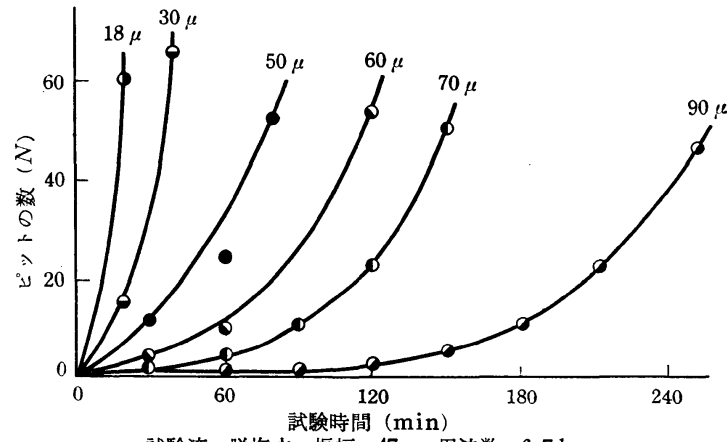

試験液：脱塩水 振幅： $47 \mu$ 周波数: $6.7 \mathrm{kc}$

図 4 クロムメッキのキャビテーション・ピッティ ングと試験時間の関係

10）を皮膜の破壊初期抵抗時間と想定し，同様の実験を 青銅メッキについて行ない, 膜厚と初期抵抗時間の関係 を図 5 に示す。図 5 中 P 印は後述する自然電極電位の解 析により求めた点であり，観測結果にほぼ一致するとと もに，これらよりクロムメッキの有効膜厚は約 $50 \mu$, 青 銅メッキはその約半分であることがわかった。

侵食断面の顕微鏡観察によれば青銅皮膜にはピンホー ルがほとえどなく表面からやや均一に侵食され，ゆるや かな公配で試験片中央部ほど膜厚が減少し, 同様の傾向 で中央部ほど素地との密着性が悪くなっている。クロム メッキについては, ピンホールが存在し，この部分から 侵食の端を発する場合とメッキ層内での艘裂破壊を生ず 


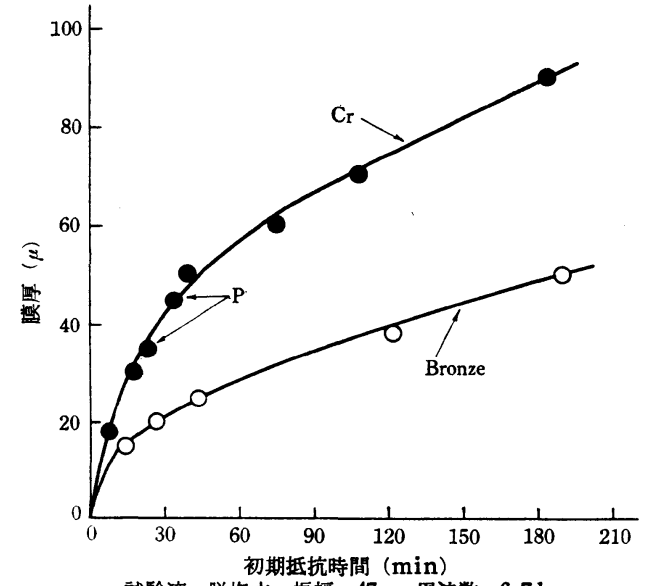

試臨液：脱塩水振幅： $47 \mu$ 周波数: $6.7 \mathrm{kc}$

图 5 メッキ膜厚とキャビテーション初期抵抗時間 の関係

る場合とがあり，いずれも進展して素地との界面で大き く鋓離し，さらに素地中のグラフォイトに沿って浸食す る。このような状態に至る経過において，電気化学的に 自然電極電位の急激な变化が起こると考えられる。

二層メッキ (青銅十クロム), 三層メッキ(青銅十ニッ ケルトクロム) については，それぞれの単独メッキより も初期抵抗時間が延長され，特にニッケルの効果が大き w。

\section{$3 \cdot 2$ キャビテーション発生下の自然電極電位}

金属被覆鋳鉄のキャビテーション腐食機構, 特に皮膜 の破壊による表面状態の変化を推察する手段として電極 電位を連続的に記録した。図 6 は無処理鋳鉄の電位变化 および腐食抑制剤添加の影響を示す。食塩溶液中におけ

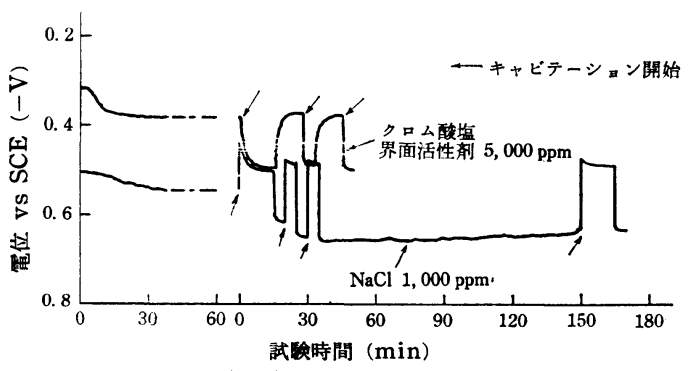

振幅: $47 \mu$ 周波数: $6.7 \mathrm{kc}$

図 6 キャビテーション発生下の自然電極電位

る電位変化は, キャビテーション発生と同時に液の攪乱 により溶存酸素の影響を受け陰陽両分極の変化が起こる 結果と推察される。中断すると鉄の腐食電位になる。抑 制绪を添加したものは無添加と逆の電位挙動を示し，キ ヤビテーションの断続により再現性のあるパターンが得 られる。この場合, クロム酸塩による不動態が空洞消滅 時の衝撃作用により破られアノード分極が減少するため と考兄られる。中断すると，すみやかに（約 10 分）復元
する。この試験条件において抑制戍による試験片の重量 減少は無添加のものとほぼ同一かむしろ増加傾向であり 防食効果は認められていない。この種の抑制绪に関して 栄, 鬼村らの詳細な報告5) とやや異なった電位挙動を示 しているのはおそらくキャビテーション発生強さの差と 思われる。

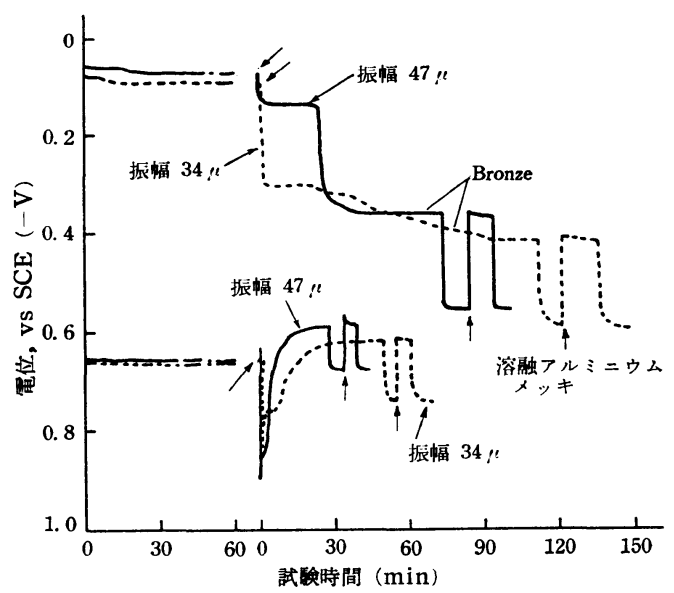

図 7 キャビテーション発生下の自然電極電位

次に金属被覆を施こした場合の電極電位測定結果の一 例を图 7 に示す。青銅メッキにおける初めの比較的小さ い変化（約 $50 \mathrm{mV}$ 单）は表面酸化物の除去などによる 影響と考えられるが，次の急激な变化（約 $200 \mathrm{mV}$ 早） はメッキ皮膜の破壊または缡離を生じた結果, 素地の電 位の影響が現われたものと考えられる。この急に落ちる 接線と続いてやや定常状態を示す接線を外挿する時間を 初期抵抗時間と仮定すれば図 5 の観測結果とほほ一致す ることがわかった。キャビテーションの断続による電位 変化は, 既に広範囲に露出した素地の影響で, 無処理の ものに見られた現象に類似している。同様の実験を低振 幅で行なうと定常電位に至るまでに長時間を要し皮膜の 耐久時間が延長される。

次に溶融アルミニウムメッキの場合, キャビテーショ ン発生直後瞬間約 $20 \mathrm{mV}$ 貴になり, その直後 $200 \mathrm{mV}$ 㫣に変わり, 以後著しく貴に変化しながら暫時定常電位 に落ち着く。この際試験片の表面状態は, 初め酸化物の 除去によりアルミニウムの活性電位に近つき，短時間内 に皮膜に書裂を生じ合金層（硬くてもろい性質のほかに グラファイトが混在することもある）を通して素地の露 出に至るものと判断される。キャビテーション発生強さ を低下させると抵抗時間は明らかに延長される。亜鉛溶 射の場合，溶融了ルミニウムメッキとほほ同様の電位挙 動を示し，明瞭な電位変化が測定され，膜の破壊までの 時間が容易に推定できるが，クロムメッキおよびステン レス鋼溶射においては比較的ゆるやかな電位変化を伴な 
い耐エロージョン性が強い。

\section{$3 \cdot 3$ 被覆のキャビテーション疲れ破䘫曲線}

前述の自然電極電位変化を利用して求めた被覆の初期 抵抗時間（繰り返し数）と振幅 (応力振幅) との間に図 8 のような関係曲線 $(S-N$ 曲線) が得られる。この被覆 キャビテーション疲れ曲線（仮称）より各被覆の耐エロ ージョン性を評価できる。すなわち一定初期抵抗時間に おける振幅の大小（時間疲れ強さに相当）により被覆の 強さを検討するものである。本試験方法の適用範囲につ いては明確でないが，振幅約 $20 \mu$ 以上のようなキャビ テーション・エロージョン領域において, 溶融メッキ, 溶射被覆類への適用は従来の重量減測定法より妥当と思

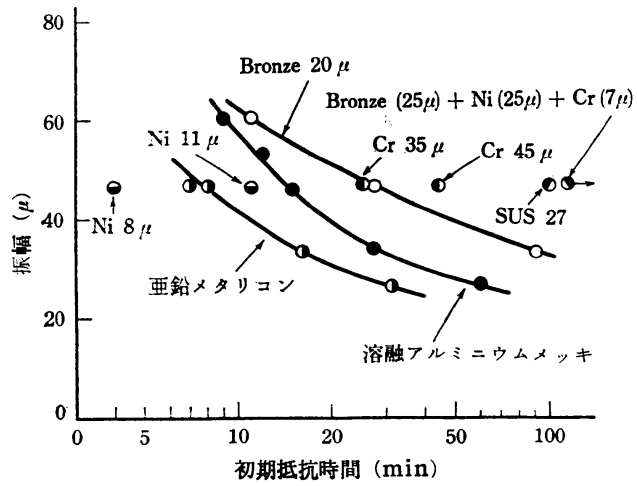

図 8 金属被覆のキャビテーション疲れ破壊曲線
われ, 約 $20 \mu$ 以下のキャビテーション・コロージョン 領域では, 腐食性環境の影響について, さらに検討を要 するものと考えられる。腐食性環境を調べる手段とし て, 定常的キャビテーション発生法に比べ断続キャビテ ーション発生法が有効とされ6)，これらについての検討 も必要であろう。

\section{4. 現 車 試 娩}

供試機関に DF 50 (MAN) 形 ディーゼル機関車を用 い，金属被覆と冷却水腐食抑制绪処理との組合わせによ るライナのキャビテーション損傷防止効果を試験した。 ライナ位置によるキャビテーション発生強度差を考虑し て各車ごとにA列 2 番, A 4, B 2 および B 4 の位置に それぞれ異種被輹を配置した。試験概要は次のとおりで ある。

\section{$4 \cdot 1$ 被覆ライナ}

ライナの冷却水に接触する部分のみに次の被覆を施 す。

（1）亜鉛溶射：平均膜厚 $150 \mu$

(2) 溶融フルミニウムメッキ; $\mathrm{Al}: 99.8 \%, 770^{\circ} \mathrm{C} 8$ 分処理，平均膜厚 $150 \mu$ (合金層を含む)

(3) ステンレス溶射 $\mathrm{A}$; 下地被覆: $\mathrm{M}_{0}>99 \%$, 約 $50 \mu$, 主溶射：SUS 27, セルローズ系樹脂シールまたは 機械加工仕上げ, 平均膜厚 $300 \mu$

ステンレス溶射 $\mathrm{B}$; 下地被覆：同 $\mathrm{A}$, 主溶射；C：

表 1 冷却水および用水の性質

\begin{tabular}{|c|c|c|c|c|c|c|c|c|c|}
\hline \multirow{2}{*}{ 腐食抑制都 } & \multicolumn{2}{|c|}{ 冷却水の性状 } & \multicolumn{7}{|c|}{ 用 水 成 分 (ppm) } \\
\hline & $\mathrm{pH}$ & 抑制都暴度 & $\mathrm{pH}$ & 溶解固形分 & $\mathrm{SO}_{4}^{2-}$ & $\mathrm{Cl}^{-}$ & $\mathrm{SiO}_{2}$ & $\begin{array}{c}\mathrm{M} \text { ×ルカリ度 } \\
\mathrm{CaCO}_{3}\end{array}$ & ${ }^{2} \mathrm{CaCO}_{3}{ }^{\text {硬 }}$ \\
\hline 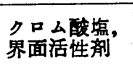 & $8.5 \sim 9.5$ & $\begin{array}{c}\mathrm{CrO}_{1} \underset{2}{2} \tau \tau \\
1,000 \sim 1,700 \mathrm{ppm}\end{array}$ & 6.6 & 63 & $\varepsilon .0$ & 15.0 & 16.9 & 12.7 & 21.2 \\
\hline 乳 化 油 & $6.1 \sim 7.8$ & 平均 $0.4 \mathrm{vol} \%$ & 7.0 & 53 & 7.2 & 13.1 & 10.1 & 28.6 & 31.7 \\
\hline
\end{tabular}

表 2 シリンダライナに発生した最大侵食媣さ $(\mathrm{mm} / 200,000 \mathrm{~km})$

\begin{tabular}{|c|c|c|c|c|c|c|c|c|c|c|c|c|c|c|c|c|c|c|c|}
\hline \multirow{2}{*}{ 金属被夏 } & \multirow{2}{*}{ 抑制 剂 } & \multicolumn{4}{|c|}{ A 2} & \multicolumn{4}{|c|}{ A 4} & \multicolumn{4}{|c|}{ B 2} & \multicolumn{4}{|c|}{ B 4} & \multicolumn{2}{|c|}{$\begin{array}{l}\text { 备ライナ中 } \\
\text { 深さの }\end{array}$} \\
\hline & & a & $\mathrm{b}$ & c & $\mathrm{d}$ & a & b & c & $\mathrm{d}$ & a & $\mathrm{b}$ & c & $\mathrm{d}$ & $\mathrm{a}$ & $\mathrm{b}$ & c & $\mathrm{d}$ & 平均 & $\begin{array}{l}\text { 最大 } \\
\text { 深さ }\end{array}$ \\
\hline 亜鉛溶射 & 乳公化酸㙁 & $\begin{array}{l}1.53 \\
0.79\end{array}$ & $\mathbf{N}$ & $\stackrel{0.48}{N}$ & $\stackrel{\mathbf{N}}{\mathbf{N}}$ & \begin{tabular}{|l|}
1.43 \\
1.03
\end{tabular} & $\frac{\mathbf{N}}{\mathbf{N}}$ & $\left|\begin{array}{c}N \\
0.63\end{array}\right|$ & $\stackrel{\mathbf{N}}{\mathbf{N}}$ & $|\overline{0.62}|$ & $\bar{N}$ & $0 . \overline{57}$ & $\bar{N}$ & $\left|\begin{array}{l}0.14 x \\
0.64\end{array}\right|$ & $|0.14 x|$ & \begin{tabular}{|l|}
0.52 \\
0.93
\end{tabular} & $\stackrel{\mathbf{N}}{\mathbf{N}}$ & $\begin{array}{l}1.19 \\
0.84\end{array}$ & $\begin{array}{l}1.53 \\
1.03\end{array}$ \\
\hline $\begin{array}{l}\text { 溶融フルミ } \\
=\text { ウムメッキ }\end{array}$ & 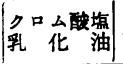 & $1 . \overline{52}$ & $\bar{N}$ & $0 . \overline{68}$ & 0.46 & $\left|\begin{array}{l}0.14 \times \\
2.08\end{array}\right|$ & $\begin{array}{c}0.14 \times \\
N\end{array}$ & $0.14 \times$ & $\begin{array}{c}\mathrm{N} \\
0.72 \\
\end{array}$ & $\mid$\begin{tabular}{l|}
1.37 \\
0.98
\end{tabular} & $\begin{array}{c}\mathrm{N} \\
0.43\end{array}$ & $\mid \begin{array}{l}1.10 \\
1.10\end{array}$ & $\stackrel{\mathbf{N}}{\mathbf{N}}$ & \begin{tabular}{|l|}
1.38 \\
0.95
\end{tabular} & $\left|\begin{array}{c|}N \\
0.60\end{array}\right|$ & $\begin{array}{l}1.64 \\
0.55\end{array}$ & $\stackrel{N}{N}$ & $\begin{array}{l}1.05 \\
1.41\end{array}$ & $\begin{array}{l}1.64 \\
2.08\end{array}$ \\
\hline $\begin{array}{l}\text { ステンンス鍓 } \\
\text { 溶 }\end{array}$ & 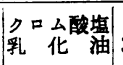 & $\begin{array}{c}\mathrm{N}^{*} \\
3.20^{*}\end{array}$ & $\mathbf{N}$ & $\stackrel{\mathrm{N}}{1.10}$ & $\stackrel{\mathbf{N}}{\mathbf{N}}$ & \begin{tabular}{|c|}
$\mathrm{N}$ \\
1.49 \\
\end{tabular} & $\mathbf{N}$ & $\mid$\begin{tabular}{c|}
$\mathrm{N}$ \\
0.44
\end{tabular} & $\mathbf{N}$ & \begin{tabular}{|l|}
$0.25 *$ \\
$1.10 *$
\end{tabular} & $\stackrel{\mathbf{N}}{\mathbf{N}}$ & $\stackrel{\mathrm{N}}{\mathrm{N}}$ & $\stackrel{\mathbf{N}}{\mathbf{N}}$ & $\overline{\mathrm{N}}$ & $\overline{\mathrm{N}}$ & $\bar{N}$ & $\overline{\mathrm{N}}$ & $\begin{array}{l}0.08 \\
1.45\end{array}$ & $\begin{array}{l}0.25 \\
3.20\end{array}$ \\
\hline 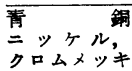 & $\mid \begin{array}{ll}ク \text { 口公酸㙁 } \\
\text { 乳 }\end{array}$ & $\begin{array}{c}\mathrm{N} \\
0.03^{+}\end{array}$ & $\frac{\mathrm{N}}{0.03^{+}}$ & $\begin{array}{c}\mathrm{N} \\
0.03^{+} \\
\end{array}$ & $\begin{array}{c}\mathrm{N} \\
0.03+ \\
\end{array}$ & $\overline{\mathrm{N}}$ & $\overrightarrow{\mathrm{N}}$ & $\overline{\mathrm{N}}$ & $\overline{\mathrm{N}}$ & $\begin{array}{c}0.03^{+} \\
\mathrm{N}\end{array}$ & $\stackrel{0.03+}{\mathrm{N}}$ & $\begin{array}{c}0.03+ \\
\mathrm{N}\end{array}$ & $\begin{array}{c}0.03+ \\
\mathrm{N}\end{array}$ & $\stackrel{\mathbf{N}}{\mathbf{N}}$ & $\stackrel{N}{N}$ & $\mathbf{N}$ & N & $\begin{array}{l}0.01 \\
0.01\end{array}$ & $\begin{array}{l}0.03 \\
0.03\end{array}$ \\
\hline
\end{tabular}

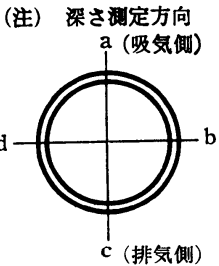

(単位: $\mathrm{mm}$ )

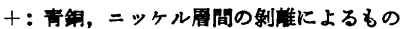

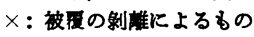

*: ステンレス銚 $\mathrm{A}$ ，他はステンレス堸 $\mathrm{B}$

$\mathrm{N}$ ：侵食を全く発生しないるの 
$0.15, \mathrm{Si}: 0.58, \mathrm{Mn}: 8.43, \mathrm{Ni}: 4.18, \mathrm{Cr}: 18.05$, ᄀ エノール系樹脂シールまたは機械加工仕上げ，平均膜厚 $300 \mu$

(4) 青銅, ニッケル, クロムメッキ

メッキ条件湔述のキャビテーション用試験片と同一 だ，膜厚はそれでれ青銅メッキ20 $20 \mu$, クロムメッキ7 $4 \mu$

\section{2 冷却水防食処理}

冷却水系統全般の防食上，現車試験で既に効果を確涊 している抑制剤を適用し表 1 に示す冷却水処理を行なっ た。

\section{$4 \cdot 3$ 試験結果および考察}

供試被覆ライナの防食状態，侵食進展速度などを調查。 一るために, 約 10 万 $\mathrm{km}$ 運転後, 代表的供試ライナに つき中間検査を行ない, 約 20 万 $\mathrm{km}$ 走行後, 全ライナ の腐食調査を行なった。損傷の侵食深さは顕溦鏡を用い て, 各ライナの発生個所ごとに数点以上測定し, そのけ 最大深さ定各被晐別にまとめたものを表 2 に示す。ライ ナ素地の最大損賃深さと速転走行キロとの閔係を図 9 : 示士。約 20 万 $\mathrm{km}$ 走行後の特徽ある腐食例定図 $10 \mathbf{a} \sim$ e に示す。

これらの試験結果の大要は,

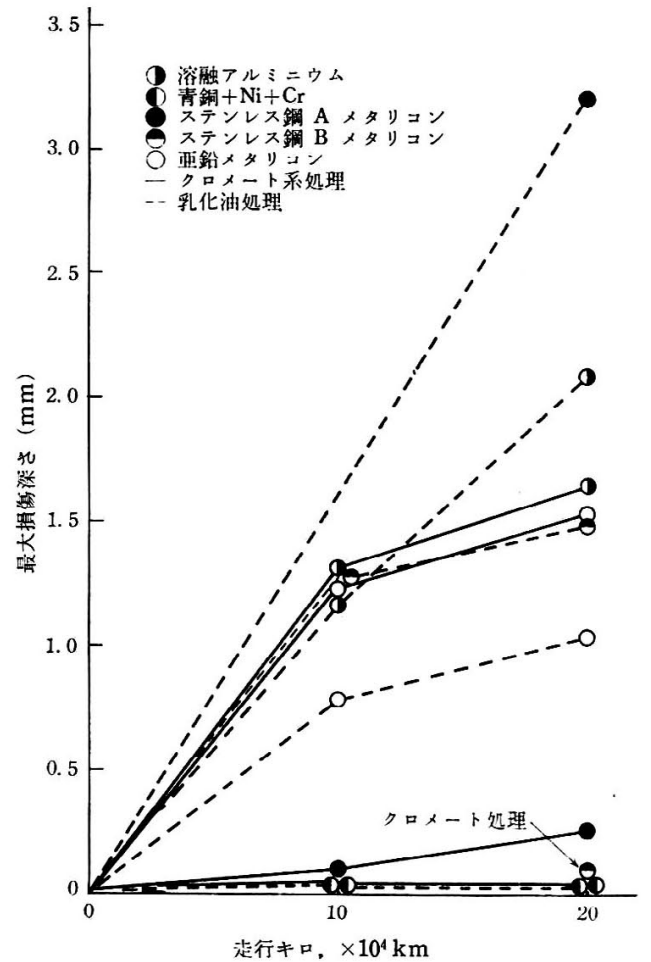

図 9 ライナ最大損傷染さと走行キロの関係

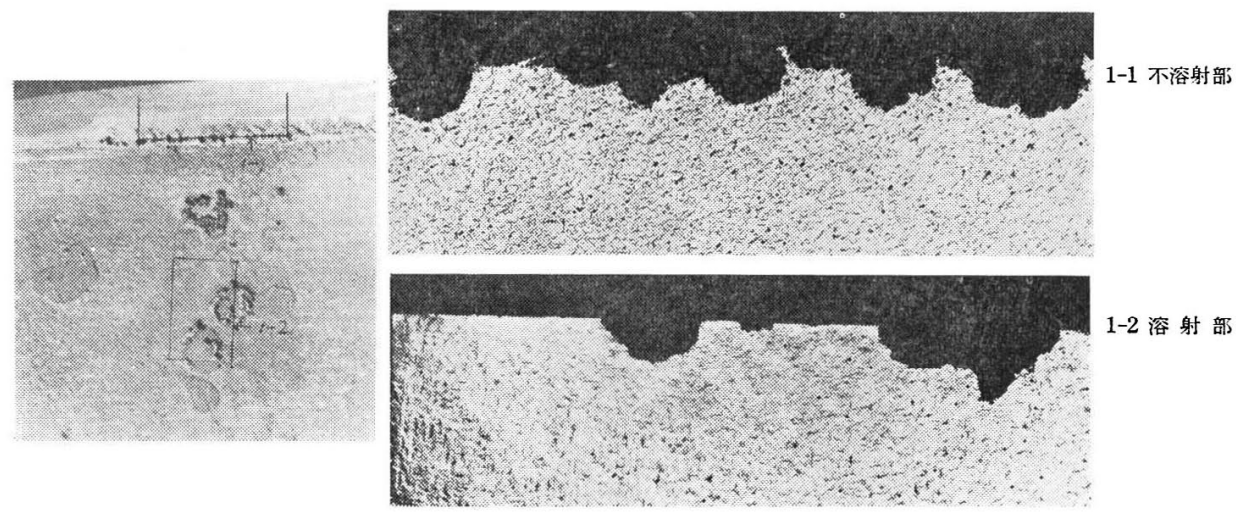

（a）ク口公酸塩処理，亜鉊溶射に発生した孔食とその断面

$\times 5$

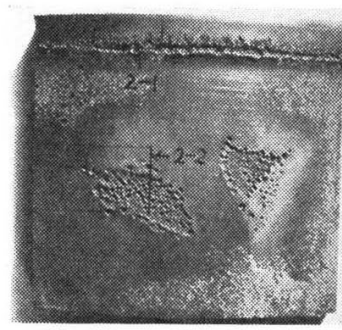

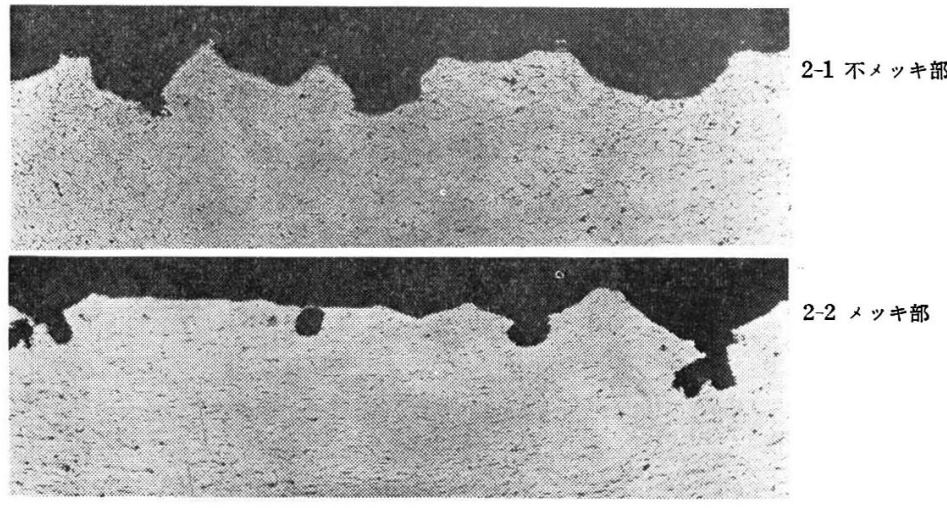

$\times 5$

(b) 乳化油処理, 溶融フルミニウムメッキのかい食断面とその断面 

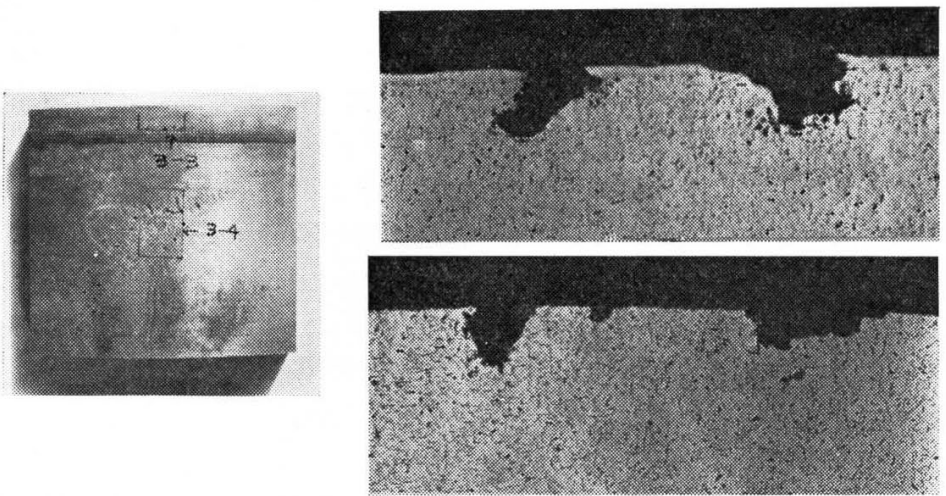

（c）乳化油処理，ステンレス鋼 B 溶射発生した損侮とその断面
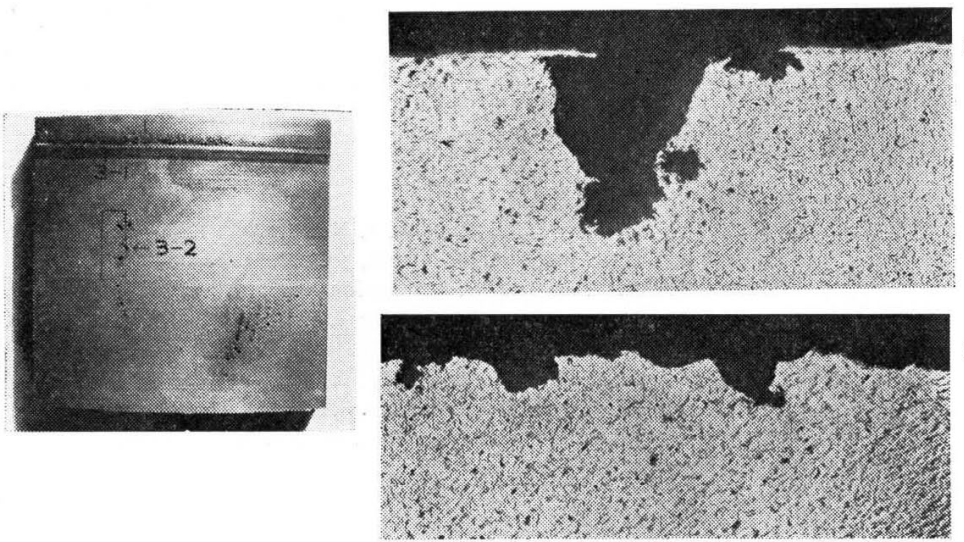

（d）乳化油処理スステンレス鋼 A 溶射に発生した損矰とその断面

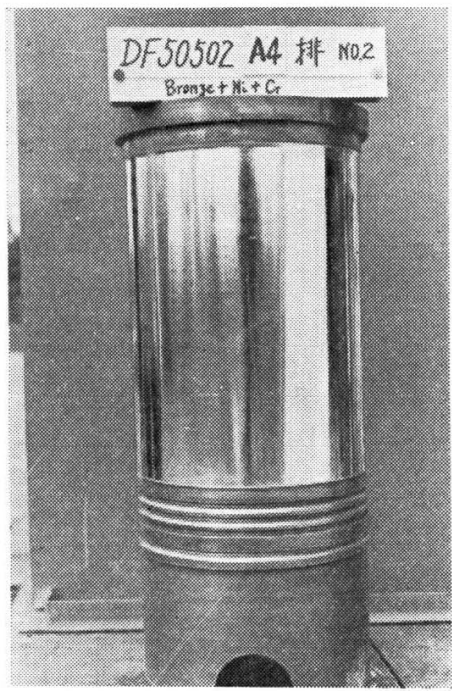

（e）乳化油処理，青銅 $+\mathrm{Ni}+\mathrm{Cr}$ メッキ

図 10 約 20 万 $\mathrm{km}$ 走行後の各種金属被覆シリンダライナのキャビテーション損傷
(2)上下かん(嵌) 合部 3-4 溶 射層

3-3 不溶射部

$\times 5$

3-2 溶 射層

$3-1$ 不溶射部

$\times 5$

\section{(1) 青銅, ニッケル, クロム三層メッキライナ は最も良好で, 冷却水の クロム酸塩および乳化油 による腐食抑制戍処理に おいて，それぞれ損傷を 完全に防止し得た。 \\ (2) ステンレス鋼溶射 ライナは無処理に比べ損 傷面積法顕著に減少され たが，深い孔食を発生す ることがあり, 特に乳化 油処理においてその傾向 がみられた。}

(3) 溶融フルミニウム メッキライナの損傷面積 注比較的広く, 潰食状に 進展したが, クロム酸塩 処理に㧍いて, 侵食速度
（1）孔食またはかい（潰）食状の損傷はスラスト側 (A 列吸気側，B 列排気側）に著しく，これと $180^{\circ}$ の反対 側に弱く発生, さらにこれらと $90^{\circ}$ の両側に弱く起こる 傾向を示す。
が軽減された。

（4）亜鉛溶射ライナはクロム酸塩処理において，孔食 の発生域が著しく減少され，かつ侵食軽減効果が認めら れたが，乳化油処理に扮いては走行 10 万 $\mathrm{km}$ 以内にほ 
とえど膜は剔脱した。

以上シリンダライナに発生した損傷の進展について, ライナ表面に局部的に強くかつ断続的なキャビテーショ ンが発生するものと想定すれば, 空洞消滅時の衝撃圧に よる瞬間的活性面の露出と抑制剤による防食化成被覆の 補修に大きく関係するものと思われる。被覆の活性電位 が素地より貴である場合, 素地の腐食傾向を示し（たと えばステンレス鋼 $\mathrm{A}$ の侵食), 单の場合（たとえば亜鉛， フルミニウム）は素地の防食作用を示すことが考えられ るが，冷却水中の腐食抑制剂および溶存酸素の作用など 腐食性環境の影響を十分考慮する必要がある。本機関ラ イナの完全損傷防止のためには, 被覆の硬さ（たとえば クロムメッキの場合, $\mathrm{Hv}$ 約 800), 耐食性, 素地に対す る強度などが要求され, さらに冷却水防食処理は不可欠 と思われる。また実用的には, 要求される運転走行キ口 により, 内面摩耗速度を考虑の上, 適当な金属被覆を選 定することもできるだろう。

\section{5. 結言}

磁わい振動法によりキャビテーション発生下の自然電 極電位の挙動から金属被覆のキャビテーション初期抵抗 時間が推察できる。金属被覆鋳鉄に対して振幅と初期抵 抗時間との間に皮膜のキャビテーション疲れ破壊曲線を 画き, この曲線の性質から被覆の耐キャビテーション・
エロージョン性を検討した。その結果耐エロージョン性 は次のようである。

青銅 $(25 \mu)+\mathrm{Ni}(25 \mu)+\mathrm{Cr}(7 \mu)>\mathrm{SUS} 27>$ 青銅

$(20 \mu)>$ 溶融アルミメッキ>亜鉛溶射

実車のライナに金属被覆を適用して冷却水腐食抑制绪 処理の併用において，青銅 $+\mathrm{Ni}+\mathrm{Cr}$ 三層メッキで損傷 を完全に防止し得, ステンレス鋼溶射, 溶融了ルミニウ ムメッキおよび亜鉛溶射はかなりの軽減効果を有し最大 侵食深さ $1.5 \sim 3.0 \mathrm{~mm} / 200,000 \mathrm{~km}$ で，いずれの損傷 部分にも重裂は発生していない。

限られた被覆について, 実験室試験と実車試験の対比 を試みたが，かなり異なった結果が得られ，さらに実車 に近い条件での実験室試験方法の検討が肝要と考えられ る。

終りに現車試験にご協力くださいました関係各位に深 く感謝の意を表します。（昭和 39 年 3 月 27 日受理）

\section{文献}

1）栄, 鬼村：新三菱重工技報, 5, No. 3 (1963)

2) 路木：防鉵技㭪, 10, No. 11, 481 (1961)

3) L. A. Glikman: Corrosion-Mechanical Strength of Metals, (Translated by J.S. Shapiro) (1962)

4) J.Z. Lichtman, D. H. Kallas, C. K. Chatten \& E.P. Cochran: Corrosion, 17, No. 10, 119 (1961)

5）栄，鬼村：防触技衍，12，No. 3, 149 (1963)

6) M.S. Plesset: Corrosion, 18, No. 5, 181 t (1962) 